Magdalena Perkowska

University of Białystok

\title{
THE INFLUENCE OF EU LAW ON POLISH CRIMINAL LAW FOR THE PREVENTION OF ILLEGAL IMMIGRATION
}

\section{INTRODUCTION}

EU law has a significant effect on the development of Polish law. This applies to all the fields of law, including criminal law and regulations for the prevention of illegal immigration to the European Union. The EU's regulations on this matter have brought about a change in Polish criminal law, both in the Polish Criminal Code (Kodeks karny; hereinafter abbreviated "k.k.") and other Polish legislation defining offences and petty offences in this area. The aim of this article is to analyse the influence of the EU regulations on Polish criminal law for the prevention of different types of illegal immigration. I will consider the following European regulations: 1) the Council Framework Decision 2002/946/JHA of 28 November 2002, on the strengthening of the penal framework to prevent the facilitation of unauthorised entry, transit and residence; 2) Council Directive 2002/90/EC of 28 November 2002 defining the facilitation of unauthorised entry, transit and residence 3) Directive 2009/52/EC of the European Parliament and of the Council of 18 June 2009 providing for minimum standards on sanctions and 
measures against employers of illegally staying third-country nationals; and 4) the Council of Europe Convention on the Prevention of Terrorism.

\section{Regulations ON ILLEGAL IMMIGRATION}

The first step taken by the Polish legislator to prevent illegal inmmigration was the implementation of the Council Framework Decision 2002/946/JHA of 28 November 2002, on the strengthening of the penal framework to prevent the facilitation of unauthorised entry, transit and residence; and Council Directive 2002/90/EC defining the facilitation of unauthorised entry, transit and residence. On these grounds the Polish legislator penalised acts undertaken for financial and personal gain involving the assisting of illegal immigration (see the Explanatory Memorandum on the proposed amendment to k.k.). ${ }^{1}$ Art. $264 \mathrm{a} \$ 1 \mathrm{k} . \mathrm{k}$. penalises the unlawful enabling and facilitation of another person's illegal stay in the Republic of Poland. ${ }^{2}$ Art. 264a k.k. was a reaction to the rising influx and illegal residence of immigrants resulting from Poland's increased attractiveness. Illegal immigration of this type would not have been possible without the help of third parties offering such opportunities. Nevertheless, Art. 264a k.k. provides for the mitigation or even waiving of the prescribed penalties in exceptional cases. ${ }^{3}$

According to the Polish legislator, not every case of assistance offered to illegal immigrants calls for the strict imposition of the penalty stipulated under Art. 264a $\$ 1$ k.k. In exceptional cases where the perpetrator has

1 Uzasadnienie Projektu Ustawy o zmianie ustawy - Kodeks karny oraz niektórych innych ustaw. Sejm Rzeczypospolitej Polskiej; Prezes Rady Ministrów, Warszawa, 8 stycznia 2004. Druk nr 2407. Hereinafter referred to as "Explanatory Memorandum to k.k."

Ustawa z 6 czerwca 1997 r. Kodeks karny. Dziennik Ustaw 2018, Item 1600.

Z. ĆWiąKalski, [in:] Kodeks karny. Część szczególna, II: Komentarz do art. 117-277 k.k., ed. A. ZoLL, Warszawa 2013, p. 1454. 
not received any financial gain, on the grounds of Art. 264a $\$ 2$ k.k. the court may mitigate or even waive the penalty. ${ }^{4}$

Art. 264 k.k. refers to the illegal crossing of the Republic of Poland's borders and assistance in illegal border crossing, whereas Art. 264a k.k. concerns the offence of illegal residence on the territory of the Republic of Poland. According to E. Pływaczewski, Art. 264a k.k. protects the Polish border against illegal immigration, ${ }^{5}$ but only accords indirect protection to state security. ${ }^{6}$

Under the aforementioned provisions, a person who intends to stay or stays on the territory of the Republic of Poland illegally, i.e. without legal entitlement, commits a criminal offence; and only a foreigner, i.e. anyone who is not a Polish citizen, fits into that category. ${ }^{7}$ Therefore, while Art. 264a $\$ 1$ k.k. does not expressly state that these provisions apply only to foreigners, this can be deduced on the grounds of Ustawa o cudzoziemcach (the Polish act on foreigners), which regulates the conditions for foreigners' residence on the territory of the Republic of Poland. ${ }^{8}$

Another important change is the introduction of stiffer penalties for the offence defined in Art. $264 \$ 3 \mathrm{k} . \mathrm{k}$. for assistance in the illegal crossing of the Polish border, with a prison sentence from six months to eight years, in compliance with the penalty prescribed in Art. 1. 3. of EU

4 P. Gensikowski, Odstąpienie od wymierzenia kary w polskim prawie karnym, Warszawa 2011, p. $182 \mathrm{ff}$.

5 E. PŁywaczewski, [in:] Kodeks karny. Komentarz, ed. M. Filar, Warszawa 2012, p. 1197.

6 E. PŁywaczewski, A. Sakowicz, [in:] Kodeks karny, część szczególna. II: Komentarz do artykułów 222-316, eds. A. WĄSEK, R. ZAwŁOCKI, Warszawa 2010, p. 534; M. Perkowska, The Impact of the Migration Crisis on Polish Immigration and Criminal Law, [in:] Irregular Migration as a Challenge for Democracy, eds. E. KużelewskA, A. Weatherburn, D. Kloza, Intersentia Cambridge-Antwerp-Portland 2018, p. 211-213.

7 On the grounds of Art. 3. 2. of Ustawa z 12 grudnia 2013 r. o cudzoziemcach (the Polish act on foreigners), Dziennik Ustaw 2013, Item 1650.

8 R.A. Stefański, Przestępstwo umożliwienia lub ułatwienia nielegalnego pobytu (art. 264a k.k.), «Prokuratura i Prawo»11/2005, p. 8; M. PerkowskA, E. Jurgielewicz, Zwalczanie nielegalnej migracji w polskim prawie karnym - wybrane aspekty implementacji prawa Unii Europejskiej, «Białostockie Studia Prawnicze» 15/2014, pp. 71-82. 
Council Framework Decision 2002/946/JHA. ${ }^{9}$ Prior to the amendment, the minimum penalty was a prison sentence of three months, and the maximum was 5 years.

Framework Decision 2002/946/JHA and Directive 2002/90/EC require infringements referred to and defined thereunder to be liable to effective, proportional, and deterrent penalties. Framework Decision 2002/946/JHA requires that assistance in illegal entry or transit (also the instigation, participation or attempt thereof) be punishable by prison sentences with a maximum sentence of not less than eight years, if committed by a criminal organisation, or if the offence endangered the lives of persons involved in its commission. Hence, under Framework Decision 2002/946/JHA, the maximum sentence of 8 years' in prison is applicable only if the offender was acting within a criminal organisation or endangered the lives of the illegal immigrants. The Polish legislator has simplified this regulation and only increased the penalty for the arranging of illegal border crossing. The Explanatory Memorandum to the amendment to k.k. simply says that the penalty was adjusted to comply with the requirements prescribed under Art. 1.3. of Framework Decision 2002/946/JHA. ${ }^{10}$ No analysis or explanation is offered whether such a change is necessary in Polish law. I will present the types of sentences handed down on the grounds of Art. $264 \$ 3$ k.k. in 20092017 on offenders convicted for the handling of arrangements for illegal border crossing.

9 Uzasadnienie dostosowawczego charakteru Projektu Ustawy o zmianie ustawyKodeks karny oraz niektórych innych ustaw. Sejm Rzeczypospolitej Polskiej; Prezes Rady Ministrów, Warszawa, 8 stycznia 2004. Druk nr 2407, p. 14; W. Grzeszczy , Zmiany w prawie karnym wprowadzone ustawa z dn. 16 kwietnia 2004 r., «Prokuratura i Prawo» 9/2004, p. 74-76; C. NowAK, Wpływ procesów globalizacyjnych na polskie prawo karne, Warszawa 2014, p. 335.

10 Uzasadnienie dostosowawczego charakteru Projektu Ustawy o zmianie ustawy Kodeks karny oraz niektórych innych ustaw. Sejm Rzeczypospolitej Polskiej; Prezes Rady Ministrów, Warszawa, 8 stycznia 2004. Druk nr 2407, p. 14. 
Table 1. Convictions under Art. $264 \$ 3$ k.k. in 2009-2017

\begin{tabular}{|l|c|c|c|c|c|}
\hline \multirow{2}{*}{ Year } & Convictions & Fine & $\begin{array}{c}\text { Community } \\
\text { sentence }\end{array}$ & Prison sentence & $\begin{array}{c}\text { Suspended pri- } \\
\text { son sentencet }\end{array}$ \\
\hline 2009 & 98 & 2 & 0 & 96 & 70 \\
\hline 2010 & 106 & 2 & 0 & 104 & 86 \\
\hline 2011 & 114 & 3 & 0 & 111 & 97 \\
\hline 2012 & 65 & 1 & 0 & 64 & 49 \\
\hline 2013 & 73 & 0 & 0 & 73 & 59 \\
\hline 2014 & 77 & 1 & 0 & 76 & 66 \\
\hline 2015 & 100 & 1 & 1 & 98 & 88 \\
\hline 2016 & 113 & 11 & 4 & 98 & 91 \\
\hline 2017 & 117 & 14 & 8 & 95 & 84 \\
\hline
\end{tabular}

Source: MS RP (Ministry of Justice of the Republic of Poland) ${ }^{11}$

Not many offenders were convicted under Art. $264 \$ 3 \mathrm{k} . \mathrm{k}$. in this period. The highest figure was 117, for 2017; and the lowest was 65 in 2012. However, it would be hard to determine a trend for the rate of change, as the Polish criminal procedure takes a considerable amount of time. Court proceedings can take a long time, and a conviction may be quite distant in time from the commission of the offence. The offence defined under Art. $264 \$ 3 \mathrm{k} . \mathrm{k}$. is liable to a prison sentence from 6 months to 8 years. However, as Table 1 shows, the sentences Polish judges handed down also included fines or community (non-custodial) sentences. This is possible under Art. 37a k.k., which gives the judge the option to sentence an offender to a fine or a community sentence if the statutory maximum penalty for the offence does not exceed eight years in prison. This applies to Art. $264 \$ 3 \mathrm{k} . \mathrm{k}$. as well. Only $4 \%$ of the offenders were sentenced to a fine and $1.5 \%$ to a community sentence. Prison sentences were handed down on $94.5 \%$ of the offenders; however; 690 of them (out

11 Cf. https://isws.ms.gov.pl/pl/baza-statystyczna/opracowania-wieloletnie/ (accessed 15 Iul. 2019). 
of a total of 815) had their sentences conditionally suspended. Polish courts may conditionally suspend a prison sentence if it does not exceed one year (until 30 June 2015 if it did not exceed two years). This shows that in $2009-2017$ over $85 \%$ of the offenders received lenient penalties which did not restrict their liberty. Secondly, a question arises whether there is a need for the Polish k.k. to have a maximum penalty of eight years on the grounds of Framework Decision 2002/946/JHA for the assistance of illegal border crossing. The practice of Polish jurisprudence shows that the prison sentences pronounced under Art. $264 \$ 3 \mathrm{k} . \mathrm{k}$. were not high - in fact they were very low. The maximum penalty in k.k. is up to eight years, while Polish judges usually handed down sentences of one year (or at most 2 years). What is more, a detailed analysis showed that none of the prison sentences handed down on the grounds of Art. 264 $\$ 3$ k.k. in 2009-2017 exceeded five years. Only in 15 cases did judges pass prison sentences of over three years, yet under 5 years. This means that the aggravation of the maximum penalty brought in under the impact of EU law was redundant, as Polish judges did not find sufficient grounds in the provisions to pass prison sentences of over five years. In my opinion, it is more important to deprive offenders of the potential gains from the arrangement of illegal border crossing than to put them in prison. The aim of the legislation should be to stop them from drawing a profit, even if this is not expressly said in Art. $264 \$ 3 \mathrm{k} . \mathrm{k}$.

\section{REgULATIONS ON THE ILLEGAL EMPLOYMENT OF FOREIGNERS}

The Polish legislator took another step to implement the EU law on illegal immigration by adopting the provisions of Directive 2009/52/ WE/EC of the European Parliament and of the Council of 18 June 2009 providing for minimum standards on sanctions and measures against employers of illegally staying third-country nationals, and incorporating them in a new legislative act known as Ustawa z 15 czerwca 2012 r. o skutkach powierzania wykonywania pracy cudzoziemcom przebywającym wbrew przepisom na terytorium Rzeczypospolitej 
Polskiej (the Act on Liability for the Employment of Illegal Immigrants on Polish Territory; hereinafter referred to as "the 2012 Act" ). ${ }^{12}$

This act has met with a certain amount of criticism in the specialist publications ${ }^{13}$ mostly because it focuses on criminal provisions, some of which are lex specialis to the Polish legislation on the promotion of employment and labour market institutions (Ustawa z 20 kwietnia 2004 r. o promocji zatrudnienia i instytucjach rynku pracy; hereinafter referred to as "the Promotion of Employment Act"). ${ }^{14}$ The Promotion of Employment Act regulates employment and the rules for the employment of foreigners. It penalises the illegal employment of foreigners, treating the illegal employment of one or more foreigners as a petty offence. So the criminal provisions prescribed by Directive 2009/52/WE/EC should have been implemented in Polish law on the grounds of this act. There was no need for a new legislative act to implement the Directive's provisions. Moreover, Art. 2 of the Promotion of Employment Act formulates the definitions needed for the application of the 2012 Act. What is more, the 2012 Act is an amendment of the Promotion of Employment Act. The new act has not extended the scope of criminalisation of the illegal employment of foreigners under Polish criminal law, ${ }^{15}$ however, it has aggravated criminal liability, upgrading specific illegal acts from petty offences to offences.

Directive 2009/52/EC put a ban on the employment of citizens of third countries staying illegally on the territory of EU member states. The new legislation on the illegal employment of foreigners that came into force in Poland following Directive 2009/52/EC (i.e. the 2012 Act) narrowed down the meaning of the term cudzoziemiec (foreigner) with

12 Ustawa z 15 czerwca 2012 r. o skutkach powierzania wykonywania pracy cudzoziemcom przebywającym wbrew przepisom na terytorium Rzeczypospolitej Polskiej. Dziennik Ustaw 2012, Item 767.

13 B. KurzęPA, Karnoprawne aspekty ustawy o skutkach powierzania wykonywania pracy cudzoziemcom, «Prokuratura i Prawo»11/2018, pp. 123-124,

14 Ustawa z 20 kwietnia 2004 r. o promocji zatrudnienia i instytucjach rynku pracy. Dziennik Ustaw 2018, No. 99, Item 1001.

15 See also O. WŁoDKowski, Wątpliwości w sprawie zgodności przepisów karnych transponujacych art. 9-10 dyrektywy 2009/52/WE z prawem krajowym, "Europejski Przegląd Sądowy» 8/2013, pp. 15-23. 
respect to the general term defined in Art. 3 of Ustawa o cudzoziemcach (the Foreigners Act, last amended in 2020). Ustawa o cudzoziemcach (and Art. 2. 1. 7. of the Promotion of Employment Act) define a foreigner (cudzoziemiec) as any person who is not a Polish citizen. ${ }^{16}$

As its Explanatory Memorandum says, the main aim of the 2012 Act was to prevent illegal immigration and counteract illegal employment. ${ }^{17}$ The opportunities available for illegal employment act as a pull factor for illegal immigration. However, this Memorandum also says that legally employed foreigners have the right to keep their job; while illegally employed foreigners do not have the right to use the Polish social insurance system and the associated services and benefits. Moreover, illegal immigrants risk return obligation if discovered.

The 2012 Act prescribes criminal and administrative penalties for employers who infringe the prohibition of illegal employment. These include the liability of legal persons, and under certain circumstances also the contractor's financial liability if their subcontractor breaks the law on the employer's duties.

The implementation of Directive 2009/52/EC in Polish law has raised the liability for the illegal employment of foreigners. Under Art. 2 of the 2012 Act employers must require foreigners applying for a job to produce a valid document authorising them to stay on the territory of Poland before they may be employed. ${ }^{18}$

Art. 120. 2. of the Promotion of Employment Act penalises the illegal employment of foreigners, qualifying it as a petty offence liable to a fine from 1,000 to 30,000 PLN. The foreigner working illegally is also liable, but his fine fine is lower (up to 5,000 PLN). The 2012 Act has raised the liability by introducing two new categories of offences and aggravated types of petty offences.

16 M. Perkowska, The Impact of the Migration Crisis..., p. 213.

17 Uzasadnienie do Projektu Ustawy o skutkach powierzania wykonywania pracy cudzoziemcom przebywającym wbrew przepisom na terytorium Rzeczypospolitej Polskiej. Sejm Rzeczypospolitej Polskiej, Prezes Rady Ministrów. Warszawa, 28 grudnia 2011 r. Druk nr 210. Hereinafter "Explanatory Memorandum to the 2012 Act”).

18 A. DrAвEк, Nielegalne zatrudnienie w prawie polskim, Warszawa 2012, p. 320. 
Under the Promotion of Employment Act, persons who employ many foreigners staying on the territory of the Republic of Poland without a valid residence permit are liable to a fine or a community sentence. This Act prescribes a similar penalty for the persistent employment of a foreigner staying on the territory of the Republic of Poland, provided that the offences are closely connected with the offender's business activity. ${ }^{19}$

Art. 9 of the 2012 Act has raised the liability for what was a petty offence under Art. 120. 1. of the Promotion of Employment Act, as the legislator has made the illegal employment of foreigners a criminal offence. The two acts of legislation appear to be at odds with each other ${ }^{20}$ but in fact that is not so, because their subject matter is not identical. In the case of the petty offence defined under the Promotion of Employment Act, the legislator used the term "illegal employment," whereas the offence defined in the 2012 Act means "the simultaneous employment of many foreigners staying on the territory of the Republic of Poland without a valid residence permit." ${ }^{21}$ However, "illegal employment" is a broader term, as it encompasses both "the simulatenous employment of many foreigners staying on the territory of the Republic of Poland without a valid residence permit" and other cases, such as legal residence but without a work permit. Thus, in cases where only a few foreigners (i.e. an insignificant number) staying on the territory of the Republic of Poland without a valid residence permit have been employed illegally, the applicable provision is Art.120. 1. of the Promotion of Employment Act; whereas if a significant number of foreigners have been employed illegally, the applicable provision is Art. 9. 1. of the 2012 Act.

To write this article, I used the statistical data published by the Polish Ministry of Justice for the number of convictions on the grounds of the 2012 Act. It has been in force since July 2012, but according to the Ministry's data, up to the end of 2017 there were no convictions at all on the grounds of this new legislation. I asked Państwowa Inspekcja

\footnotetext{
19 M. Perkowska, The Impact of the Migration Crisis..., p. 214.

20 See also: O. WŁodKowski, op. cit.

21 M. Perkowska, The Impact of the Migration Crisis..., p. 211-213.
} 
Pracy (PIP; Poland's national labour inspectorate) if they knew of any cases of offences committed under this Act, but they told me that to the end of 2017 there were no cases at all that needed to be reported to the criminal law enforcement authorities.

Table 2. Types of illegal employment of foreigners

\begin{tabular}{|l|c|c|c|c|}
\hline \multirow{2}{*}{ Type of violation } & \multicolumn{4}{|c|}{ Number of foreigners } \\
\cline { 2 - 5 } & 2017 & 2016 & 2015 & 2014 \\
\hline $\begin{array}{l}\text { Illegal residence in } \\
\text { Poland }\end{array}$ & 20 & 16 & 30 & 13 \\
\hline $\begin{array}{l}\text { Legal residence, no } \\
\text { work permit }\end{array}$ & 151 & 56 & 57 & 31 \\
\hline $\begin{array}{l}\text { Working in conditions } \\
\text { different from those } \\
\text { specified in work } \\
\text { permit }\end{array}$ & 1,739 & 383 & 132 & 137 \\
\hline $\begin{array}{l}\text { No work contract } \\
\text { Employed without } \\
\text { a work permit }\end{array}$ & 8,157 & 4,689 & 941 & 662 \\
\hline Total & 9,873 & 5,655 & 1,356 & 971 \\
\hline
\end{tabular}

Source: Państwowa Inspekcja Pracy ${ }^{22}$

PIP's data shows that there were only a few cases of foreigners with no residence permit working in Poland. Most cases concerned foreigners with no work permits though legally resident in Poland.

Another public body responsible for the detection of illegal employment in Poland is Straż Graniczna (the Polish border guards). According to their data, in 2017 there were 3,006 foreigners in illegal employment in Poland (the corresponding figures for 2016 were 2,648,

22 Cf. https://www.pip.gov.pl/pl/o-urzedzie/sprawozdania-z-dzialalnosci/ 97255,sprawozdanie-glownego-inspektora-pracy-z-dzialalnosci-panstwowej-inspekcji-pracy-2017.html (accessed 22 Jul. 2019). 
and 2160 for 2015). ${ }^{23}$ However, their data did not show how many of these foreigners also had no residence permit.

This confirms that the illegal employment of foreigners is not a major problem in Poland, compared to other EU countries. As the Explanatory Memorandum to the 2012 Act shows, the scale of the illegal employment of foreigners in Poland is not significant. ${ }^{24}$ So I cannot agree with B. Kurzępa, who claims that the purpose of the 2012 Act was to stop the escalation of the illegal employment of foreigners with no work permits. ${ }^{25}$

So why were there no convictions or confirmed cases of violations under the 2012 Act? One reason might be the vague languae used in this Act; another is that Ukrainian nationals accounted for the largest number of foreigners employed in Poland, also of those employed in violation of the provisions of Polish labour law. They no longer need visas to enter the EU, but they do need visas or other permits to work. So usually their residence in Poland is legal, but that need not mean they have a work permit.

Art. 1.1. of, the 2012 Act defines "the penalties for offenders who employ a foreigner staying on the territory of the Republic of Poland without a valid residence permit" (sankcje dla podmiotów powierzających wykonywanie pracy cudzoziemcowi przebywajacemu bez ważnego dokumentu uprawniajaccego do pobytu na terytorium Rzeczypospolitej Polskiej). Art. 4.3. of Directive 2009/52/EC expressly states that an employer is not liable for employing a foreigner who is staying illegally on EU territory if he has checked whether the foreigner holds a valid document which authorises him/her to stay, keeps the copy of the document for at least the duration of the employment, and has notified the appropriate authorities that the foreigner is starting employment. ${ }^{26}$

Art. 9. 1. of the 2012 Act uses a vague expression and speaks of the liability of an employer who "employs many third-country nationals staying illegally" in Poland (powierza ... wykonywanie pracy wielu

23 Data from Straż Graniczna statistical reports available at https://strazgraniczna. $\mathrm{pl} / \mathrm{pl} /$ granica/statystyki-sg/2206,Statystyki-SG.html (accessed 22 Jul. 2019).

24 Explanatory Memorandum to the 2012 Act, p. 3.

25 B. KurzęPA, op. cit., pp. 123-124.

26 Explanatory Memorandum to the 2012 Act, p. 9. 
cudzoziemcom przebywającym bez ważnego dokumentu uprawniajacego do pobytu na terytorium Rzeczypospolitej Polskiej). How many is "many"? To clear up the confusion, we may cite some of the opinions on doctrine, for example with reference to Art. 163 k.k.. Most authors say that "many" is usually over ten. ${ }^{27}$

Another vague expression comes in Art. 10 of the 2012 Act and refers to the employment of a foreigner staying on the territory of the Republic of Poland without a valid residence permit and working "under particularly exploitative working conditions" ( $w$ warunkach szczególnego wykorzystania). This offence is liable to a prison sentence of up to three years. However, in Art. 10. 3. the legislator specifies that "particularly exploitative working conditions" means conditions which are in breach of the law, degrade human dignity, and in which employees are treated in a blatantly different way, particularly with respect to their sex, from the working conditions provided for persons working legally, and which could affect their health and safety. This paragraph is of key importance, as illegally employed foreigners are at risk of violations not only of their basic employment rights but also of the fundamental human rights (wykonywanie pracy z naruszeniem prawa, uchybiajace godności człowieka i rażąco odmienne, w szczególności ze względu na płeć, w porównaniu $z$ warunkami pracy osób, którym powierzono wykonywanie pracy zgodnie zprawem, wpływające zwłaszcza na zdrowie lub bezpieczeństwo osób wykonujacych prace). ${ }^{28}$ However, even though Art. 10. 3.) explains the meaning of "particularly exploitative working conditions," the expression "conditions which are in breach of the law, degrade human dignity, and in which employees are treated in a blatantly

27 See: Z. Ćwiąkalski, op. cit., p. 207; R.A. Stefański, Przestępstwa przeciwko bezpieczeństwu powszechnemu i w komunikacji. Komentarz, Warszawa 2000, p. 30; A. MareK, Kodeks karny. Komentarz, Warszawa 2010, p. 400; K. Bucha£A, [in:] Kodeks karny. Część szczególna, Komentarz do art. 117-277 Kodeksu karnego, ed. A. Zoll. Kraków 1999, p. 331; B. KurzęPA, op. cit., p. 127.

28 M. Duszczy K, Imigrant - pracownik. Przestrzeganie praw pracowniczych i potencjalne problemy na rynku pracy, [in:] Przestrzeganie praw cudzoziemców w Polsce, eds. P. DĄBrowski, M. Duszczy , «Biuletyn Rzecznika Praw Obywatelskich w Polsce» 11/2012, p. 32; M. PerkowskA, The Impact of the Migration Crisis..., p. 215. 
different way" is yet another vague formulation open to a wide margin of interpretation.

Art. 10 also penalises the employment of foreigners who are victims of the offence defined in Art. 189a. 1. k.k., that is human trafficking.

Art. 11 defines an aggravated type of the petty offence defined by Art. 120 of the Promotion of Eemployment Act, i.e. the persistent employment of a foreigner staying on the territory of the Republic of Poland without a valid residence permit, provided this work is not related to the employer's business activity. This paragraph has another ambiguous word, uporczywie "persistently." ${ }^{29}$ According to the Polish doctrine, the word relates to the habitual behaviour of a psychologically motivated offender who is unrelenting and persists in his repeat offences. ${ }^{30} \mathrm{It}$ is difficult to prove such a stubborn attitude. Proving the offender's recidivistic frame of mind is another problem. However, if an offender persistently employs one foreigner who is staying on the territory of the Republic of Poland without a valid residence permit, but the work is related to the employer's business activity, the employer commits an offence under Art. 9. 3. of the 2012 Act.

One of the penalties prescribed in Art. 12.1. for employers who employ foreigners in violation of the law is the forfeit of access to the the European Structural Funds, the Cohesion Fund and the European Fund for Fisheries, as well as to resources for the implementation of the Common Agricultural Policy. Moreover, offenders under Arts. 9 and 10 are also obliged to return any funds they have received from these resources within 12 months of conviction. These sanctions are similar to those applicable to a collective entity under Art. 9 of Ustawa

29 M. Perkowska, E. Jurgielewicz, op. cit. More on the term „persistent” M. Szewczy K, [in:] Kodeks karny. Część szczególna, II: Komentarz do art. 117-277 k.k., ed. A. Zoll, Warszawa 2013, p. 909; A, MAREK, op. cit., s. 476-477; Z. Siwik, [in:] Kodeks karny. Komentarz, ed. M. FILAR, Warszawa 2012, s. 1049. Judgement V KKN 504/2000, «OSNKW» 7-8/2001, poz. 57.

30 A. Zoll, [in:] Kodeks karny. Część szczególna, II.1:. Komentarz do art. 117-211a, eds. W. Wróbel, A. Zoll, Warszawa 2017, p. 592; M. Mozgawa, [in:] Kodeks karny. Komentarz, ed. V. Konarska-Wrzosek, Warszawa 2017, p. 570, also: Judgement of Appellation Court in Wrocław from 19.02.2014 r., II AKa 18/14, «Lex» nr 1439334. 
z 28 października 2002 r. o odpowiedzialności podmiotów zbiorowych za czyny zabronione pod groźbą kary (the Polish act on the criminal liability for offences committed by collective entities). ${ }^{31}$

Other important issues that need to be analysed are the penalties for offences and petty offences. The petty offence (wykroczenie) defined in Art. 120 of the Promotion of Employment Act means "the employment of foreigners in violation of the law, which is liable to a fine from 1,000 to 30.000 PLN." All the offences defined in Art. 9 of the 2012 Act are liable to a fine or a community sentence. This means that under Art. $33 \$ 1 \mathrm{k} . \mathrm{k}$. , the minimum penalty may be 100 PLN. Thus, the minimum penalty for the offence can be lower - as much as 10 times lower - than the penalty for the petty offence, as the minimum penalty under Art. 120 of the 2012 Act is 1,000 PLN. This inconsistency is due to the oversight of the legislator, who did not compare the penalties and gave the option of smaller fines being imposed for offences than for petty offences for the same type of prohibited acts. This inconsistency should be amended as soon as possible.

\section{REgUlations CONCERNING THE PREVENTION OF TERRORISM}

The latest amendment made in Polish criminal law is for Art. 259a k.k., which has introduced a new offence, the crossing of the Polish border with the intention to commit a terrorist act on the territory of another state. ${ }^{32}$ The grounds for this regulation are Ustawa z 10 czerwca

31 Ustawa z 28 października 2002 r. o odpowiedzialności podmiotów zbiorowych za czyny zabronione pod groźbą kary, Dziennik Ustaw 2002 No 197, Item 1661.

32 Art. 259a kk states that whoever crosses the border of the Republic of Poland to commit a terrorist offence on the territory of another state or the offence stipulated under Art. 255a or Art. 258. 2. or 4. k.k. i.e., the distribution or public presentation of content that could facilitate the commission of a terrorist offence, or obtaining access to such content to commit such an offence, participation in a terrorist offence, receiving training for terrorism, participation in an organised group or association whose purpose is to commit a terrorist offence, forming or leading an organised group or association whose purpose is to commit a terrorist offence, is liable to the penalty a prison sentence from 3 months to 5 years. 
2016 r. o działaniach antyterrorystycznych (the Anti-Terrorism act of 10 June 2016).

As the Explanatory Memorandum to its draft bill points out, one of the aims of this Act is to introduce criminal law provisions pursuant to the Additional Protocol with regard to the Council of Europe Convention on the Prevention of Terrorism concluded in Warsaw on 16 May 2005, which the Republic of Poland signed. ${ }^{33}$ Therefore, the Act introduces numerous amendments and new types of offences concerning the activities of so-called "foreign fighters." Art. 4. 2. of the Protocol states that "Each Party shall adopt such measures as may be necessary to establish 'travelling abroad for the purpose of terrorism;"34 as defined in paragraph 1 , from its territory or by its nationals, when committed unlawfully and intentionally, as a criminal offence under its domestic law. In doing so each Party may establish conditions required by and in line with its constitutional principles."

Under Art. 259a k.k., an offender who crosses the Polish border has to manifest an intent to commit an offence on the territory of another state, so this regulation is confusing. A doubt arises whether it refers to entering or leaving the Republic of Poland. We may assume that both cases are criminalised. ${ }^{35}$ K.k. uses the expression "whoever crosses the border" (Kto przekracza granice), which may mean entering or leaving the Republic of Poland, therefore the perpetrator may be stopped while leaving Polish territory. According to this provision, any state other than the Republic of Poland may be considered "another state." Therefore, any person who leaves Poland to commit an offence in another state,

33 Council of Europe Convention on the Prevention of Terrorism concluded in Warsaw on 16 May 2005, Dziennik Ustaw 2008 No 161, Item 998.

34 Travelling abroad for the purpose of terrorism means travelling to a State, which is not that of the traveller's nationality or residence, for the purpose of the commission of, contribution to or participation in a terrorist offence, or the providing or receiving of training for terrorism (Art. 1. 1. of the Protocol).

35 Z. ĆWIĄKALSKi, [in:] Kodeks karny. Część szczególna, II: Komentarz do art. 117-277 k.k., ed. W. Wróbel, A. Zoll, Warszawa 2017, p. 560; A. Michalska-Warias [in:] Kodeks karny. Część szczególna, II: Komentarz. Art. 222-316, eds. M. KRóLIKowski, R. Zawıocki, Warszawa 2017, p. 404; A. Herzog, [in:] Kodeks karny. Komentarz, ed. R.A. StefańsKi, Warszawa 2018, p. 1648. 
as well as any person who crosses Poland in transit for another country to commit a terrorist attack is liable under Polish criminal law. The Polish provisions are in accordance to the provision of Art. 4. 1. of the Protocol. An offender can be held criminally liable regardless of whether he crossed the Polish border legally or illegally. In the latter case, Art 49a of Kodeks Wykroczeń (the Polish Code of Petty Offences) is applicable in conjunction with Art. $264 \$ 2 \mathrm{k}$.k., as both apply to liability for the illegal crossing of the Polish border. ${ }^{36}$

It may be disputed whether criminal prosecution solely on the grounds of an individual's expressions of motivation, and without more concrete evidence of intent to actually carry out a major criminal offence, appears to criminalise expressions or manifestations rather than objective criminal conduct. This risk is heightened where the conduct subject to criminalisation is an attempt to carry out an offence. The Draft Additional Protocol should have laid down a prerequisite for a sufficiently direct connection with a major criminal offence and stipulated the need to establish a clear and unequivocal intent. ${ }^{37}$ The Polish Ombudsman took a similar approach and observed that the provisions of Art. 259a k.k. shift liability significantly to before the time when the public good was actually infringed, which raises serious doubts from the perspective of a democratic state based on the rule of law and the principle of proportionality. Moreover, the Draft Bill did not provide persuasive arguments that the way it formulated the types of prohibited acts was absolutely necessary, useful and proportional. ${ }^{38}$

The penalties introduced for the offence defined in Art 259a k.k. appear to be reasonable, bearing in mind the geographical location of Poland and transit routes across the country, as well as illegal immigration, and the smuggling of goods or terrorists who intend to reach other European states. As the Polish border guard authority has indicated, significant

36 M. Perkowska, The Impact of the Migration Crisis ..., p. 217-218.

37 Amnesty International, Draft Additional Protocol to the Council of Europe Convention on the Prevention of Terrorism, 2015, IOR 60/1281/2015, p. 8.

38 Rzecznik Praw Obywatelskich, Opinia do projektu ustawy o działaniach antyterrorystycznych (Druk nr 516), p. 19. Cf. https://www.rpo.gov.pl/pl/content/projekt-ustawy-o-dzialaniach-antyterrorystycznych-opinia-rpo (accessed 15 Jul. 2019). 
changes occurred in the structure of illegal immigration to Poland in 2014, and new priorities appeared in the mechanisms to prevent it, due to developments such as a rising level of activity by extremist groups of Islamic fundamentalists in Europe. Therefore, monitoring the traditional type of refugee and economic immigration from Asia and Africa and its prevention have become more and more important in the light of mutual security. ${ }^{39}$

Persons who intend to reach other European countries to carry out a terrorist attack may resort to legal methods such as tourist trips or applications for refugee status, as well as activities which appear to be legal, such as the abuse of administrative procedures for the grant of a temporary residence permit to legalise their stay on the territory of Poland, obtaining a residence permit in connection with a marriage of convenience or fake enrolments at institutions of higher education, as well as attempts to obtain a residence permit for Poland on the basis of misinformation concerning their stay in other EU member states (this applies mainly to nationals of Asian countries). ${ }^{40}$ Such people also use illegal means like using someone else's document (the "look-alike" method) or travel documents obtained on the basis of counterfeited documents (obtaining the attestation of an untruth under false pretences). ${ }^{41}$

However, from the procedural point of view it is crucial to prove intent "to commit a terrorist offence" under Art. 259a k.k.. One question may be putd in this context: which elements of an offender's behaviour, or objects and documents in their possession could prove their intentions? The fact that a foreigner produces forged or another person's documents, or ones obtained under false pretences, does not definitively mean they are planning to carry out a terrorist attack. As Amnesty International

39 Ministerstwo Spraw Wewnętrznych i Administracji (the Polish Ministry of Interior Affairs and Administration), Raport o stanie bezpieczeństwa w Polsce w 2014 roku, Warszawa 2015, p. 102.

$40 \quad$ Ibidem, p. 104.

41 Ministerstwo Spraw Wewnętrznych i Administracji (the Polish Ministry of Interior Affairs and Administration), Raport o stanie bezpieczeństwa w Polsce w 2013 roku, Warszawa 2014, p. 113. 
points out, under no circumstances should a defendant bear the burden of proof to establish that their travel to or presence in a specific area was for a legitimate purpose, in keeping with the principle of presumption of innocence. In criminal proceedings the burden of proof lies solely with the prosecution. ${ }^{42}$

The determination of the purpose for which an offender crossed the border of the Republic of Poland calls for a detailed examination of motives, which of course may be revealed by offenders themselves, or which may result from the evidence collected. Unless such additional evidence is available, even the fact that a terrorist offence (or another of the offences defined in Art. 259a k.k.) has been committed abroad does not signify the incidence of the attributes of the offence, because the prosecution still has to prove that the offender intended to commit the offence already at the time when he was crossing the Polish border. Also the multi-level subjective aspect (the actions offenders take to commit the crime, which is also characterised by their specific mindset) can make it extremely difficult to provide irrefutable evidence regarding their behaviour. ${ }^{43}$

Needless to say, according to the data of the Polish Ministry of Justice, to the end of 2018 no one was convicted under Art. 259a k.k.

\section{Conclusions}

The introduction of Art. 264a. 1. into the Polish Criminal Code to penalise assisting illegal residence on Poland was a necessary measure. This type of assistance is different from helping with illegal border crossing. From the practical point of view, it is easier to prove assisting an immigrant's illegal residence than helping him to cross the border illegally. On the other hand, at the beginning of their stay in Poland, immigrants who have a valid visa or other document allowing them to

42 Amnesty International, Draft Additional Protocol to the Council of Europe Convention on the Prevention of Terrorism, 2015, IOR 60/1281/2015, p. 8; M. PERKOWsKA, The Impact of the Migration Crisis..., p. 216-217.

43 A. Michalska-Warias, op. cit., p. 406-407. 
stay in the country legally may cross the border legally; however, when their visa (or other permit) expires, their status changes to that of illegal immigrants, and this is the point at which persons assisting them to stay in Poland illegally are in breach of the law.

In my assessment of the aggravation of the penalty for the offence under Art. $264 \$ 3 \mathrm{k} . \mathrm{k}$., I have to say that it has been unnecessary. This is so firstly because Framework Decision 2002/946/JHA rules that assistance in illegal entry or transit is liable to a prison sentence with a maximum of not less than eight years if the offence was committed as an activity conducted by a criminal organisation, or if it endangered the lives of the persons subject of the offence. This is not a case to which Art. $264 \$ 3$ k.k. is applicable. Secondly, because Polish judges have not found it necessary within the scope of their discretionary powers to hand down sentences of over five years in prison (previously five years was the maximum sentence).

The implementation of Directive 2009/52/WE/EC in the new Polish Act of 15 June 2012 is more controversial, first of all because implementation did not necessitate a new legislative act. Instead, a new regulation should have been introduced in the Promotion of Employment Act, which contains provisions penalising all the different forms of illegal employment of foreigners. Secondly, the 2012 Act has been remarkably redundant over the last five years, not because offences have not been committed on the Polish labour market, but rather because difficulties have emerged with the implementation of the new regulations. Most of the problems are due to the vague expressions such as the employment of "many third- country nationals staying illegally" in Poland, or "working in exploitative conditions." Art. 120 of the Promotion of Employment Act already covers all the types of illegal employment of foreigners. All that the introduction of new petty offences and offences in the 2012 Act has done is to aggravate liability in a few cases. Practice has shown that this was a pointless move, as up to the end of 2018 there were no convictions on the grounds of the 2012 Act.

The effectiveness of the new measures (except for the introduction of Art. 264a k.k.) has been negligible or in fact nil. The new aggravated penalty in Art. 264. 3. k.k. is not being exercised; neither are the 
criminal provisions under the 2012 Act nor Art. 259a k.k. Incidentally, this criminalisation has been fairly symbolic, ${ }^{44}$ as in Poland illegal immigration is generally a minor problem, unlike the situation in other European states, and the same applies to the illegal employment of foreigners.

\section{The Influence of EU Law on Polish Criminal Law for the Prevention of Illegal IMMigration}

\section{Summary}

The main aim of this paper is to examine whether or not the legal amendments to Polish criminal law for the prevention of illegal immigration were necessary and if so, whether they are proportional to the perceived threat posed by such migration. The paper discusses the implementation of the relevant EU legislation, viz. Council Framework Decision 2002/946/JHA of 28 November 2002 on the strengthening of the penal framework to prevent the facilitation of unauthorised entry, transit and residence; Council Directive 2002/90/EC defining the facilitation of unauthorised entry, transit and residence; Directive 2009/52/WE/EC of the European Parliament and of the Council providing for minimum standards on sanctions and measures against employers of illegally resident third-country nationals; and the Council of Europe Convention on the Prevention of Terrorism; and the direct effects of this legislation on Polish criminal law as presented in the Polish Criminal Code (Arts. $264 \mathrm{a}$ and 259a k.k.), the aggravation of the penalties in Art. $264 \$ 3 \mathrm{k} . \mathrm{k}$.; and the institution of Ustawa o skutkach nielegalnego zatrudnienia cudzoziemców nielegalnie przebywających na terytorium Polski (the Act on Liability for the Employment of Illegal Immigrants on Polish Territory). In addition, the article considers the effectiveness of the new criminal provisions, particularly on the basis of the number of convictions.

44 L. Gardocki, Zagadnienia teorii kryminalizacji, Warszawa 1990, p. 180. 


\section{WPEYW PRAWA EUROPEJSKIEGO NA POLSKIE PRAWO KARNE} W ZAKRESIE ZWALCZANIE NIELEGALNEJ IMIGRACJI

\section{Streszczenie}

Głównym celem artykułu jest ocena zmian jakie zostały dokonane zmiany w polskim prawie karnym w zakresie zapobiegania nielegalnej migracji. Autorka stara się udzielić odpowiedzi na pytanie czy zmiany takie są konieczne, a jeśli tak, to czy są one proporcjonalne do postrzeganego zagrożenia związanego z migracją. Analizie poddano implementację europejskich aktów prawnych tj. Decyzji Ramowej Rady 2002/946/ WSiSW z 28 listopada 2002 r. w sprawie wzmocnienia systemu karnego w celu zapobiegania ułatwianiu nielegalnego wjazdu, tranzytu i pobyt, Dyrektywa Rady 2002/90/WE z 28 listopada 2002 r. definiującej ułatwianie nielegalnego wjazdu, tranzytu i pobytu, Dyrektywy Parlamentu Europejskiego i Rady 2009/52/WE/WE z 18 czerwca 2009 r. przewidującej minimalne normy w odniesieniu do kar i środków stosowanych wobec pracodawców zatrudniających nielegalnie przebywających obywateli krajów trzecich, a także Konwencji Rady Europy o zapobieganiu terroryzmowi. Te akty prawne miały bezpośredni wpływ na polskie prawo karne, którym było wprowadzenie art. 264a kk, 259a kk, zaostrzenie kary w art. $264 \$ 3 \mathrm{kk}$ i wprowadzenie ustawy o skutkach nielegalnego zatrudnienia cudzoziemców nielegalnie przebywających na terytorium Polski. Ponadto autorka poddała analizie skuteczność nowych przepisów karnych, zwłaszcza na podstawie liczby wyroków skazujących.

Słowa kluczowe: imigracja; nielegalne zatrudnienie; implementacja przepisów.

Keywords: immigration; illegal employment; implementation of EU law. 


\section{Literature}

Amnesty International, Draft Additional Protocol to the Council of Europe Convention on the Prevention of Terrorism, 2015, IOR 60/1281/2015.

Bucha£a K., [in:] Kodeks karny. Część szczególna, Komentarz do art. 117-277 Kodeksu karnego, ed. A. Zoll. Kraków 1999.

ĆwiąKaLski Z., [in:] Kodeks karny. Część szczególna, II: Komentarz do art. 117-277 k.k., ed. W. WróBeL, A. Zoll, Warszawa 2017.

ĆWiąKAlski Z., [in:] Kodeks karny. Część szczególna, II: Komentarz do art. 117-277 k.k., ed. A. Zoll, Warszawa 2013.

Drabeк A., Nielegalne zatrudnienie w prawie polskim, Warszawa 2012.

Duszczyк M., Imigrant - pracownik. Przestrzeganie praw pracowniczych i potencjalne problemy na rynku pracy, [in:] Przestrzeganie praw cudzoziemców $w$ Polsce, eds. P. DĄBrowski, M. Duszczyk, «Biuletyn Rzecznika Praw Obywatelskich w Polsce» 11/2012, p. 25-33.

GARDOCKI L., Zagadnienia teorii kryminalizacji, Warszawa 1990.

Gensikowski P., Odstapienie od wymierzenia kary w polskim prawie karnym, Warszawa 2011.

GrZeSzCZy K W., Zmiany w prawie karnym wprowadzone ustawa $z$ dn. 16 kwietnia 2004 r., «Prokuratura i Prawo» 9/2004, p. 77-89.

Herzog A., [in:] Kodeks karny. Komentarz, ed. R.A. Stefański, Warszawa 2018.

KURZĘPA B., Karnoprawne aspekty ustawy o skutkach powierzania wykonywania pracy cudzoziemcom, «Prokuratura i Prawo» 11/2018, p. 123-140.

LaCH A., [in:] Kodeks karny. Komentarz, ed. V. Konarska-Wrzosek, Warszawa 2016.

Marek A., Kodeks karny. Komentarz, Warszawa 2010.

Michalska-Warias A., [in:] Kodeks karny. Część szczególna, II: Komentarz. Art. 222-316, eds. M. Królikowski, R. Zawıocki, Warszawa 2017.

Ministry of Interior Affairs and Administration, Raport o stanie bezpieczeństwa w Polsce w 2014 roku, Warszawa 2015.

Ministry of Interior Affairs and Administration, Raport o stanie bezpieczeństwa w Polsce w 2013 roku, Warszawa 2014.

Mozgawa M. [in:] Kodeks karny. Komentarz, ed. V. Konarska-Wrzosek, Warszawa 2017,

NowAк C., Wpływ procesów globalizacyjnych na polskie prawo karne, Warszawa 2014, p. 335.

Ombudsman, Opinia do projektu ustawy o działaniach antyterrorystycznych (print no 516). 
Perkowska M., Jurgielewicz E., Zwalczanie nielegalnej migracji w polskim prawie karnym - wybrane aspekty implementacji prawa Unii Europejskiej, «Białostockie Studia Prawnicze»15/2014, p. 71-82.

Perkowska M., The Impact of the Migration Crisis on Polish Immigration and Criminal Law, [in:] Irregular Migration as a Challenge for Democracy, eds. E. Kużelewska, A. Weatherburn, D. Kloza, Intersentia Cambridge-Antwerp-Portland 2018.

PŁywaczewski E., [in:] Kodeks karny. Komentarz, ed. M. Filar, Warszawa 2012. PŁywaczewski E., Sakowicz A., [in:] Kodeks karny, część szczególna, Tom II: Komentarz do artykułów 222-316, eds. A. WĄSEK, R. ZAWŁOCKI, Warszawa 2010. SiwıK Z., [in:] Kodeks karny. Komentarz, ed. M. FilaR, Warszawa 2012.

Stafański R. A., Przestępstwo umożliwienia lub ułatwienia nielegalnego pobytu (art. 264a k.k.), «Prokuratura i Prawo»11/2005, , p. 7-17.

Stefański R.A., Przestępstwa przeciwko bezpieczeństwu powszechnemu i w komunikacji. Komentarz, Warszawa 2000.

Szewczy M., [in:] Kodeks karny. Część szczególna, II: Komentarz do art. 117-277 k.k., ed. A. ZolL, Warszawa 2013.

WŁodKowski O., Wątpliwości w sprawie zgodności przepisów karnych transponujących art. 9-10 dyrektywy 2009/52/WE z prawem krajowym, "Europejski Przegląd Sądowy» 2013, p. 15-23.

Zoll A., [in:] Kodeks karny. Częśćszczególna, II. 1: Komentarz do art. 117-211a, eds. W. Wróbel, A. Zoll, Warszawa 2017. 